\title{
PAUL GOMA - INTRODUCERE ÎN BIOBIBLIOGRAFIA SCRIITORULUI OPOZANT, PÂNĂ ÎN 1989
}

\section{PAUL GOMA - INTRODUCTION A LA BIOBIBLIOGRAPHIE D'UN ECRIVAIN DE L'OPPOSITION JUSQU'EN 1989}

\author{
Flori BĂLĂNESCU ${ }^{1}$ \\ https://doi.org/10.52744/9786062613242.10
}

Rezumat: Scriitorul român Paul Goma (1935-2020), născut în România Mare şi refugiat de război din Basarabia natală în România micşorată la vârsta de 8 ani şi jumătate, a avut un traseu biografic şi literar aparte. Natura sa mereu în răspăr cu autoritatea l-a adus încă din timpul liceului în conflict cu Securitatea, principala instituție represivă a regimului comunist, apoi în timpul studenției, când a devenit deținut politic. Apariția romanului Ostinato în Occident, în 1971, a dus la ruptura ireconciliabilă cu regimul comunist, culminând în 1977 cu organizarea Mişcării pentru drepturile omului şi cu azilul politic în Franța.

Cuvinte cheie: Azil politic; Cenzură; Detenție politică; Drepturile Omului; Represiune; Securitate

Résumé : L'écrivain roumain Paul Goma (1935-2020), né en Bessarabie, dans la Grande Roumanie, et réfugié de guerre à l'âge de 8 ans et demi dans une Roumanie réduite, a eu un parcours biographique et littéraire particulier. Sa nature, toujours en contradiction avec les autorités, l'a mis déjà au lycée en conflit avec la Securitate (principale institution répressive du régime communiste), puis pendant ses études, où il sera même fait prisonnier politique. L'apparition du roman Ostinato en Occident, en 1971, conduit à une rupture irréconciliable avec le régime communiste, qui culmine en 1977 avec l'organisation du Mouvement pour les droits de l'homme et l'asile politique en France.

Mots-clés : Asile politique ; Censure ; Détention politique ; Droits de l'homme ; Répression ; Sécurité.

1 Cercetător ştiințific III la Institutul Național pentru Studiul Totalitarismului, flowerbalanescu@gmail.com 
„În scopul executării planului de compromitere şi neutralizare a lui «GRAMA» vom proceda astfel:

A. Lansarea în țară a versiunii că «GRAMA» lucrează pentru o «putere străină» va fi realizată în ordinea şi mediile menționate mai jos: 1. Într-o discuție organizată cu Constantin Chiriță de la Uniunea

Scriitorilor în care vom aborda «unele probleme» legate de viitoarea Conferință a scriitorilor în mod «confidențial», după ce discuțiile au fost canalizate în acest sens, îi destăinuim că «GRAMA» nu întâmplător face ceea ce face, ci la anumite indicații şi cu un scop bine determinat, dar în niciun caz în interesul țării.”2

Scriitorul Paul Goma s-a născut în ziua de 2 octombrie 1935, în satul Mana, com. Vatici, jud. Orhei, provincia Basarabia, România, în familia învățătorilor Eufimie şi Maria Goma, întemeietori de şcoală în satul Mana, unde i-a trimis statul român, după absolvirea Şcolii Normale (am spune azi, Liceul Pedagogic). Maria făcuse Şcoala Normală la Chişinău, iar Eufimie la Orhei. Primul născut al tinerei familii, Petre, a murit înainte de a împlini un an. Deşi conform tradiției locului următorul născut ar fi trebuit să poarte prenumele Pavel (Sf. Petru şi Pavel), viitorul scriitor a fost botezat Paul, după un consilier regal care se numea Paul Goma. Eufimie şi Maria aflaseră, probabil din presa timpului, de acesta şi îl percepuseră ca pe un soi de talisman purtător de noroc pentru copilul lor. Paul D. Goma3 era, în fapt, rezident regal al ținutului Dunărea de Jos. Nu cunoaştem existența unor semne aducătoare de noroc, cert este că scriitorul basarabean a ajuns celebru şi reper literar, moral şi istoric, spre deosebire de rezidentul regal cu acelaşi nume.

$\mathrm{Cu}$ frontul în spate, în martie 1944 familia se refugiază în Transilvania, primul popas la Sibiu, într-un Centru pentru refugiați, apoi în satul Gusu, jud. Sibiu, unde Maria şi Eufimie au fost repartizaţi învățători. Comisiile de „repatriere” în Uniunea Sovietică lucrau din plin la depistarea basarabenilor şi bucovinenilor refugiați în țară din calea războiului, pentru a-i trimite înapoi în „patria sovietică”, în realitate, în Gulag. Cei trei membri ai familiei Goma au fost prinşi pe 13 ianuarie 1945 şi au scăpat de Siberia numai după ce Eufimie, ajutat de micul Paul, a falsificat actele de identitate. La începutul anului şcolar 1946-1947, Paul Goma a devenit elev bursier al Şcolii Normale „Andrei Şaguna” din Sibiu.

\footnotetext{
211 mai 1972, „Notă privind măsurile ce se vor lua pentru îndeplinirea planului de compromitere şi neutralizare a lui «GRAMA»", în ACNSAS (Arhivele Consiliului Național pentru Studierea Arhivelor Securității), Fond Informativ, dosar nr. 2 217, vol. 2, f. 31 .

3 Cf. „Arhive personale şi familiale”, vol. 1, Repertoriu arhivistic, disponibil la http://arhivelenationale.ro/site/wp-content/uploads/2017/o8/Arh._personale_si_ familiale_I.pdf (accesat la 1.07.2020)
} 
Între timp, se petrece „reforma învățământului” şi în septembrie 1948 află că este elev în clasa a VII-a Ciclul Doi la Gimnaziul din Şeica Mare, jud. Târnava Mare.

Tot într-o zi de 13 ianuarie, dar 1949, cei doi învățători Goma, stabiliți acum în satul Buia, ,împreună cu majoritatea locuitorilor adulți din satul Buia, sunt «ridicați şi duşi» - nu se ştie unde"4. Paul Goma avea 13 ani. Şi-a căutat părinții la Sibiu, Alba Iulia, Sighişoara, însă aceştia erau închişi la Securitatea din Mediaş. Maria a fost eliberată la sfârşitul lunii mai, iar Eufimie în august, ultimul dintre cei arestați. În toate aceste luni, Paul a „locuit” „în gări și la poarta Securității din Mediaş (vezi Ostinato, În Cerc, Gherla, Gardă inversă, Patimile după Pitești, Bonifacia, Arta reFugii, Astra, Sabina, Roman intim...)"5.

La începutul anului şcolar 1949-1950, Paul a intrat prin concurs elev bursier în clasa a VIII-a la Liceul „Gheorghe Lazăr" din Sibiu şi o lună mai târziu a descoperit biblioteca „Astra” (despre care scrie în romanul omonim şi în Sabina, Roman intim). Biblioteca va juca un rol major în formarea lui Paul Goma, cu valențe de prag de trecere din mai multe perspective. În decembrie 1949 este închisă cu motivul oficial „pentru inventar", în realitate, începuse epurarea cărților.

În primăvara anului 1952, Paul era elev în clasa a X-a, între timp citise destul de mult, avea câteva teme majore de preocupare, între care „partizanii” (rezistența din munți) şi, factor agravant, ținea un jurnalintim. Prin urmare, vigilența ideologică nu l-a ocolit şi a fost chemat („convocat”) la sediul Securității din Sibiu, unde a fost reținut opt zile. Vorbise în clasă despre „partizani”, iar jurnalul-intim era codificat. Pedeapsa: întors toamna din vacanță, află că a fost exmatriculat cu interdicția de a intra în vreo altă şcoală din România. După o săptămână la Liceul din Sighişoara, i s-a cerut să plece. Nu a fost primit nici la Braşov. Salvarea a venit de la Liceul „Negru Vodă” din Făgăraş, pe care l-a absolvit în vara anului 1953. După o încercare de a intra la Institutul de Artă Cinematografică, este încadrat la cerere în învățământ şi devine „instructor superior de pionieri” la Şcoala elementară din comuna Dacia, raionul Rupea, apoi la liceu, în oraşul Rupea. Un an mai târziu, în 1954 dă examen simultan, atât la Facultatea de Filologie a Universității din Bucureşti, cât şi la Institutul de literatură şi critică literară „Mihai Eminescu”, care înlocuia „Şcoala” purtând acelaşi nume - supranumită Fabrica de Scriitori. Este admis la ambele şi alege Institutul. Nu pentru mult timp, deoarece peste încă un an acesta devine secție a Filologiei. Din toamna anului 1955 încep conflictele studentului Goma, cu precădere la

4 „Biobibliografie”, Paul Goma, Culoarea curcubeului (Cutremurul oamenilor 77), Bălănescu (2015, 19-49).

5 Ibid. 
seminare. Profesorii Radu Florian, Tamara Gane, Mihai Gafița, T. G. Maiorescu, A. Hoajă, Mihai Novicov, G. Macovescu, Iorgu Iordan sunt cu ochii pe el. În iunie 1956 este supus ,judecății” în cadrul rectoratului Universității de către Iorgu Iordan, Al. Graur, Ion Coteanu, Leonte Tismăneanu, Radu Florian, Mihail Novicov. Participă şi „doi tovarăşi necunoscuți, în civil, de la Securitate" 6 .

Ce i se imputa studentului Paul Goma:

- la seminarul de marxism, susținuse că războiul Uniunii Sovietice contra Finlandei era „potrivit materialismului-istoric - «război injust»; «de agresiune»";

- „Moldovenii” sunt români; „limba moldovenească” este o invenție sovietică, locuitorii RSS Moldoveneşti vorbesc limba română, care este latină, nu slavă, aşa cum susținea acad. Al. Graur, aflat printre acuzatori;

- sistemul cotelor obligatorii pentru țărani „este descurajant”, „colectivizarea agriculturii o eroare economică”;

- trupele sovietice staționate pe teritoriul României sunt trupe de ocupație;

- predarea limbii ruse nu trebuie să fie obligatorie, şi aşa mai departe.

Această adevărată anchetă a durat aproximativ trei ore, timp în care Al. Graur a leşinat şi a fost scos din „,instanță”, iar colegii „de boxă” ai lui Goma (Covaci şi Albu) s-au speriat şi au trecut de partea comisiei. Situația a căpătat trăsături suprarealiste când principalul acuzator, unul dintre pionierii proletcultismului în România, Mihail Novicov, s-a înmuiat pe parcurs şi a devenit „,avocat al apărării”. Felul în care îşi aminteşte Goma acest episod are o încărcătură mai mult decât literară, are relevanță istorică:

„Tavarişci! Iel, Guoma, spri diasibiri di alț' riacțianari nicinstiț', iel ieste un riacțianar cinstit - ieu cam atâta am avu' di spus..." (Novicov devine un personaj robust în romanul Justa7). Este posibil ca intervenția pseudopedagogică a lui Novicov să fi amânat arestarea studentului. Iorgu Iordan, susținut de Ion Coteanu, îl voia arestat pe loc, în vreme ce Leonte Tismăneanu şi Radu Florian agreau exmatricularea. Intervenția lui Novicov s-a dovedit, însă, a avea cea mai mare greutate. În luna august

\footnotetext{
${ }^{6}$ Ibid.

7 În romanul Justa, Novicov ia şi apărarea personajului Toria (inspirat de scriitoarea Gloria Barna - pseudonimul Alexandrei Indrieş, colegă de facultate cu Goma, ajunsă şi ea în puşcărie): „- Ia [Eu/Ea, n.m., F.B.] nu pirmit! Ia cunuosc pi tavarăşa (şi arată spre sală, desigur şi spre Toria), ia iesti o divatatî tavarăşă, ia cinstită, di aceia pus ia prrrabliema în muod cinstit! Ia nu pirmit! Ia [Eu] zacut doisprici ani în uocnili faşiste undi ierai mata, tavarişc', când ieu zaciam la Daftana? Ci vrâstî ai matali?”, în Goma, Justa (2016, 63).
} 
1956, studentul Goma face pregătire militară la Cilibia şi acolo aude că sar fi întâmplat ceva la Poznan. Aşa a început, spune Goma, toamna budapestană (revolta antisovietică), în august, la Poznan.

Goma începuse să scrie un roman, numit provizoriu „Durerile facerii”, pe care anchetatorii îl vor folosi împotriva sa peste doar câteva luni. Din acest manuscris citise câteva fragmente la seminarele „de creație”, la clasa de proză condusă de Mihai Gafița. Dar pe 22-23 octombrie 1956 a izbucnit Revoluția Maghiară, studenții din Bucureşti se mişcau şi ei, plănuind o demonstrație de solidarizare pentru ziua de 5 noiembrie, demonstrație care nu a mai avut loc. În primele zile ale lunii noiembrie, Securitatea îi arestase pe organizatori, iar în ziua proiectatei demonstrații a ocupat Piața Universității cu camioane, securişti în civil, armată şi brigăzi muncitoreşti - „clasă muncitoare îmbrăcată în pufăici noi-nouțe, înarmată cu lanțuri de bicicletă, tuburi de plumb şi ciomege scurte, aceştia fiind, ca să zicem aşa, părinții (sau chiar bunicii, de ce nu!) Minerilor Români din 1990 şi din 1991"8.

După tentative eşuate de a se organiza cu câțiva dintre colegii săi de cămin („Matei Basarab”), Paul Goma a hotărât ca la prima şedință de UTM să predea carnetul, considerând că este o formă de protest față de ce se întâmpla la Budapesta şi în România cu colegii săi arestaţi. Nu a avut prilejul să o facă, dar a pus această acțiune pe seama personajului masculin din manuscrisul său. Mai mult, a citit fragmentul respectiv la seminarul lui Gafița. A fost ultimul gest de revoltă înainte de arestarea sa la Universitate, pe 22 noiembrie 1956, ora 13.30. Au urmat ancheta la Ministerul de Interne, procesul şi detenția. Procesul s-a desfăşurat în perioada 20 martie-3 mai 1957, încheiat cu Sentința nr. 487 (în dosarul nr. 93/1957 al Tribunalului Militar Bucureşti). Cei doi învinuiţi în acest lot: Paul Goma şi Horia Florian Popescu (28.02.1935) au fost condamnați pentru „delictul de agitație publică” (p.p. de art. 327 al. 3 Cod Penal). Deținutul CR (contrarevoluționar) Goma a fost mutat de la Securitate la penitenciarul Jilava abia la 13 aprilie 1957, unde după proces a aflat cuantumul condamnării: doi ani de închisoare corecțională. De aici, pe 25 martie 1958 (Bunavestire) 9 a fost transferat la penitenciarul Gherla. $\mathrm{Cu}$ două zile înainte de expirarea termenului, pe 19 noiembrie, în urma unei turnătorii (Anton Barbu-Panaghia), Goma şi „frontieristul” Ferdinand Piatka ${ }^{10}$ sunt torturați de Todoran, Goiciu, Istrate, Şomlea („cel Bătrân” erau doi frați Şomlea: Gavril şi Gheorghe, subofițeri la Gherla). Pe 21 noiembrie, Paul Goma este eliberat la expirarea legală a pedepsei, dar este escortat în satul-nou Lăteşti, raionul Feteşti, în Bărăgan, cu regim de

\footnotetext{
8 Biobibliografie, loc. cit.

9 De Bunavestire a şi murit, în 25 martie 2020.

10 În romanul Gherla-Lăteşti, personajul poartă numele Klapka.
} 
domiciliu obligatoriu, inițial cu condamnare administrativă de 36 de luni, majorată ulterior cu 24 de luni. Experiența grea de la Gherla i-a inspirat scriitorului crezul întregii vieți personale, literare şi civice, similar unei autentice arte poetice:

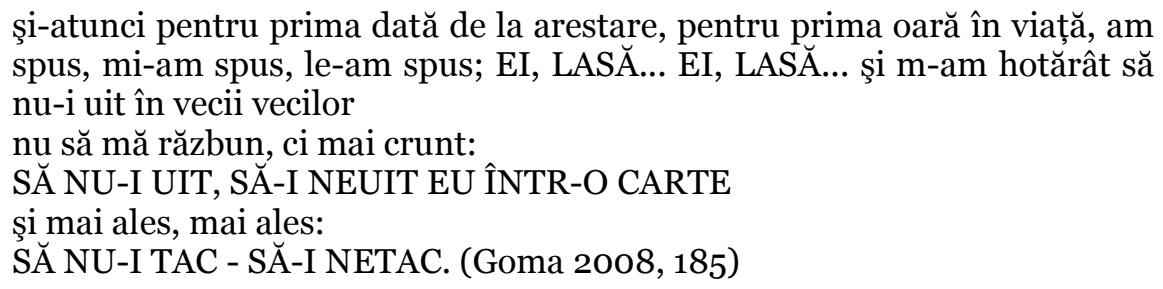

$\mathrm{Nu}$ scapă de teroare nici în domiciliu obligatoriu, acolo unde locotenentul de Securitate Ion Livescu îl hărțuieşte şi îl bate. După ridicarea restricțiilor domiciliare, între 1963-1965 Paul Goma supravieţuieşte lucrând „numai în munci necalificate şi nepermanent(izat)e: muncitor zilier în construcții, la Buhuşi, pe şantierul Casei de Cultură deci tot în domeniu, atât că în fier-beton; fotograf ambulant (nunți, botezuri, înmormântări), prin satele din Rupea şi Făgăraş; trompetist de sâmbătă-seara (baluri, nunți, hore); dezgropător de puieți la pepiniera Şercaia; descărcător-încărcător de cereale în silozul din Şercaia-Gară; muncitor necalificat la forja uzinei «Rulmentul» din Braşov; merceolog la «Agrosem» Făgăraş - în fine: «tehnician» la Serviciul Tehnic al Întreprinderii de Gospodărie a Oraşului Făgăraş (vezi Ela, Bonifacia, Adameva...)"11. Aceste preocupări de necesitate iau sfârşit în urma unui decret care permitea foştilor deținuți politici să-şi continue studiile universitare. Deşi era legal să i se aprobe înmatricularea în anul III (fusese arestat la finalul anului II), nu i se permite şi se vede nevoit să dea alt examen de admitere la Facultatea de Filologie, redevenind student în anul I, după 11 ani de la prima admitere.

În această perioadă de aşa-zisă liberalizare, în fond, una de acalmie, Goma continuă romanul pe care îl începuse la Lăteşti, în domiciliu obligatoriu, acel roman care va deveni Ostinato şi de care se leagă atât ruperea definitivă de tarele spațiului cultural românesc centralizat şi cenzurat ideologic şi afirmarea sa în spațiul editorial occidental, cât şi conflictul ireconciliabil cu regimul comunist.

În primăvara anului 1966, Goma a depus la ESPLA (Editura de Stat pentru Literatură şi Artă) manuscrisul romanului Ostinato (atunci cu titlul Cealaltă Penelopă, cealaltă Ithacă). Fostul lui profesor, Mihai Gafița, i-a răspuns că „nu se poate debuta cu un roman, numai cu un volum de proză scurtă...”, aceasta fiind, se pare, o condiție ad-hoc pentru

${ }^{11}$ Biobibliografie, loc. cit. 
cei cu pete la dosar, dar nici măcar pentru toți foştii puşcăriaşi, ci doar pentru cei care nu au colaborat cu ancheta. Prin urmare, în vara aceluiaşi an lasă la ESPLA un volum de „proză scurtă”, cunoscut ulterior sub titlul Camera de alături. Femeile au avut un rol benefic în viața lui Paul Goma. Gica Iuteş şi Sînziana Pop, intuind un viitor scriitor de forță, l-au convins pe Eugen Barbu ca Goma să debuteze în revista Luceafărul, pe care o conducea autorul romanului Groapa (şi în anii 1970 unul dintre cei mai mari denigratori ai lui Goma, în paginile revistei Săptămâna!). Pe 6 decembrie 1966 apărea povestirea Aia, căreia redacția i-a schimbat titlul în Când tace toba... Sfârşitul anului este bogat: lui Paul Goma îi mai apar în Luceafărul o proză şi un reportaj (Cetatea Făgăraşului), iar la decernarea Premiilor revistei Luceafărul pentru anul 1966 primeşte mențiune la categoria proză.

Continuă să publice şi anul următor în Gazeta literară, Viaţa Românească, Ateneu, Neuer Weg, Cravata roşie, iar în primăvara anului 1967 revista germană Neue Literatur (revistă din România) pregăteşte deja în vederea publicării un fragment din Ostinato, tradus de Anemone Latzina şi Dieter Schlesak. Atunci a început povestea lui „Goma un Soljenițîn român”. Aflat în redacția revistei de limba germană, Miron Radu Paraschivescu a văzut întâmplător fragmentul din Ostinato, a citit şi a exclamat: „Dar băiatul ăsta e un Soljenițîn român!” Cuvintele lui MRP au fost premonitorii, romanul Ostinato nu a apărut, din cauza cenzurii şi a invidiei unora dintre scriitorii editori, însă a apărut în germană şi în franceză în anul morții lui Paraschivescu, 1971. Pe pliantul de popularizare al editurii Suhrkamp din Frankfurt-am-Main stă scris (de 49 de ani!): „Ein rumänischer Solschenizyn”. Goma a recunoscut mereu influența etic-morală a lui Soljeniţîn asupra lui, însă stilurile lor sunt diferite. Exclamația de surprindere a lui MRP poate că sublinia exact acest lucru: în sfârşit, un scriitor român care va face cunoscută lumii crima politică din România, pe modelul celebrului rus. Reacția lui Eugen Ionesco, într-un interviu acordat Monicăi Lovinescu la Radio Europa Liberă, în februarie 1977, este edificatoare în acest sens:

[Paul Goma] este un excelent scriitor, este un mare scriitor, evident nu are suprafața lui Soljenițîn, că nici România nu are suprafața Rusiei sovietice, dar este moralmente de aceeaşi talie şi poate că e şi mai tare încă decât el pentru că există o inerție românească, există un fel de fatalism românesc, un fel de nepăsare metafizică. ${ }^{12}$.

Astfel, Goma a putut citi la Cenaclul condus de MRP fragmente din roman, iar Televiziunea austriacă l-a filmat; totodată, revista vieneză Literatur und Kritik a publicat un fragment, o notă biobibliografică şi un

12 În transcrierea Securității. 
studiu despre literatura română, semnate de Marie-Thérèse Kerschbaumer, viitoarea sa traducătoare în limba germană.

Circulă multe inadvertențe biografice şi literare, una dintre ele fiind legată de a doua perioadă de studenție a lui Paul Goma. În genere, se consideră că scriitorul a absolvit Filologia. În realitate, Goma nu a fost lăsat să termine facultatea nici a doua oară, ca „student bătrân”: „în urma insistențelor (în fapt: presiunilor, şantajelor securistului Victor Achim, în acel timp «ocupându-se» de studenți, câțiva ani mai târziu de scriitori) şi a şefului său Nicolae Mihai”, Goma a abandonat studiile, pentru a nu mai fi presat să cedeze şantajelor. Legat de acest episod, am descoperit în dosarul scriitorului o scrisoare olografă, în încheierea căreia spune:

1968 - Am 33 de ani, sunt student în anul II, fac de două ori pe săptămână naveta la Domneşti ${ }^{13}$, mă întrețin singur şi vreau să fiu lăsat în pace. Bucureşti, 17 februarie 1968, Paul Goma. ${ }^{14}$.

Anul 1968 este marcat de debutul editorial în volum, căruia editura i-a schimbat titlul din Moartea noastră cea de toate zilele în Camera de alături, şi de respingerea romanului Ostinato. Pe 7 august se căsătoreşte cu Ana Maria Năvodaru, iar în ziua de 22 august cade „bomba” invadării Cehoslovaciei şi este lansat în librării volumul Camera de alături. A doua zi, pe 23 august, în ciuda faptului că nu era membru al Uniunii Scriitorilor, a cerut să fie primit în Brigăzile Patriotice. Este unul dintre multele detalii rău înțelese şi intenționat îngroşate într-o tuşă defavorabilă lui Goma.

„Este trimis la plimbare, cu explicația: a) scriitorii încă nu alcătuiseră asemenea... formații; b) chiar dacă se vor constitui Brigăzi la Uniune, în ele vor intra numai membri de partid; august, 24: P.G. este chemat telefonic la sediul Uniunii Scriitorilor, unde Pop Simion, Ioanichie Olteanu și János Szász îl anunță că ideea lui a fost bună, însă dacă vrea să intre în Brigăzile Patriotice, mai întâi trebuie să intre în partid; august, 24-25: în Sala Mare a Casei Scriitorilor are loc faimoasa şedință de primire în partid a unor, în general, tineri scriitori (care ceruseră să facă parte din Brigăzi): Mariana Costescu, Aurel Dragoş Munteanu, Adrian Păunescu, Paul Schuster, Al. Ivasiuc şi Paul Goma (doar atâția să fi fost?)”15

\footnotetext{
13 „La Domneşti era internată Maria Goma, iar studentul nu mai suporta presiunile securiştilor care încercau să-l recruteze, dându-i la schimb un loc bun la sanatoriu pentru mamă. Este greu de înțeles cum poate cineva să refuze un loc de spitalizare sigur pentru mama sa imobilizată de paralizie. Paul Goma rămâne cu studiile neterminate, în timp ce mulți colegi de facultate sau de generație, şi ei trecuți prin puşcăriile politice, îşi iau diplomele, îşi găsesc locuri confortabile în noua structură socială şi politică”, în Bălănescu (2019, 28-38).

14 „Justificare biografică”, în ACNSAS, Fond Informativ, dosar nr. 2 217, vol. 3, ff. 51-55.

15 Biobibliografie, loc. cit.
} 
Efervescența transmisă de discursul din balcon al lui Ceauşescu i-a alimentat scriitorului dorința de eliberare a Basarabiei natale, traducând „curajul” lui Ceauşescu prin acum e momentul. O „nebunie” de moment, în care a crezut probabil până şi-a dat seama că Gărzile Patriotice (care ar fi urmat să se alăture eliberării Basarabiei) erau o minciună. O altă minciună a regimului comunist şi a valeților lui de la Uniunea Scriitorilor. Prin urmare, „disidența” lui Goma, care şi-ar avea originea în aderența la partid, potrivit analiştilor superficiali de toată mâna, este o minciună. Goma nu a fost niciodată membru de partid, în fapt, doar cu numele pentru scurt timp, până ce securiştii au pus mâna pe carnetul de membru. Regimului îi era ruşine cu un astfel de „membru”. Pe de altă parte, definiția „disidenței” exclusiv pe seama apartenenței la un partid politic este de mult timp depăşită.

Camera de alături (1968), volumul de debut, a rămas singura carte a lui Paul Goma publicată în România, până în 1990. A avut două cronici bune, semnate de Lucian Raicu şi de Valeriu Cristea, critici respectabili şi bine cotați ai vremii.

Ruptura ireconciliabilă cu regimul comunist şi cu scriitorimea română s-a produs pe fondul apariției în Occident a primului său roman: Ostinato, 1971, concomitent în germană şi franceză, la editurile Suhrkamp şi Gallimard. Momentul de cotitură este marcat de deschiderea dosarului de urmărire informativă de către Securitate, în martie 1971, cu numele de obiectiv „Bărbosul” („Gom”, „Grama”). În primăvara anului 1970, publică pentru ultima oară în România, un fragment din noul roman, In cerc, în România literară. I se resping toate manuscrisele depuse la edituri. Fostul său coleg de suferință, scriitorul Alexandru Ivasiuc, redactor la editura Cartea Românească, „identifică” în romanul Uşa noastră cea de toate zilele în personajul Florica pe Elena Ceauşescu şi în Iosub pe Nicolae Ceauşescu. Urmarea: Marin Preda (directorul editurii) şi Mihai Gafița resping publicarea romanului. I se interzice dreptul la semnătură, nu mai poate semna nici măcar traduceri. Soției sale şi tatălui acesteia, Petre Năvodaru, de asemenea. Cel din urmă, deşi tradusese Iosif şi fraţii săi, de Thomas Mann, nu este trecut pe carte. Apare la traducere doar Petru Manoliu.

În timp ce în Occident, în traducerea germană a Mariei-Thérèse Kerschbaumer, Ostinato este pregătit pentru publicare, în România Ceauşescu instituie Tezele din iulie. Toamna, apare romanul şi la Târgul de carte de la Frankfurt iese scandal. Delegația oficială a României îşi retrage standul, în semn de protest față de publicarea unei cărți şi unui autor care prejudiciau imaginea regimului de la Bucureşti. Ostinato a fost un succes imens, cu atât mai mult cu cât venea dintr-o țară arestată, şi nu a încetat să fie un moment definitoriu în traseul biobibliografic al scriitorului Paul Goma, un roman „fugit” din România, cum l-a numit 
Giorgio Sandri16, nu doar o carte, ci dovada materială a libertății de gândire şi expresie.

\section{„Viața mea este memorie”}

(Paul Goma)

Nu este întâmplător că regimul de la Bucureşti a adoptat tocmai în acest context Legea nr. 23/17 decembrie 1971 privind apărarea secretului de stat în Republica Socialistă România. Capitolul 1, art. 5, prevedea că „se interzice scoaterea, difuzarea sau publicarea în străinătate a lucrărilor sau scrierilor de orice fel, care ar putea prejudicia interesele statului român" ${ }^{17}$. Prin publicarea în lumea liberă a unor cărți respinse de cenzură şi de editori în România, Goma „trăda” frecvent patria, prejudiciind interesele statului român. Dar şi pe ale scriitorilor conformi şi obedienți. Este de înțeles că regimul, prin intermediul Securității şi al Uniunii Scriitorilor, încerca să scape de originea „răului”, prin plecarea lui Goma din țară. În aprilie 1972, scriitorul a fost chemat de preşedintele Uniunii Scriitorilor, Zaharia Stancu: „am primit dispoziție să-ți dăm paşaport" 18; Paul Goma a primit paşaport fără să-l ceară, deşi atunci când a cerut nu i s-a acordat. Intuind jocul autorităților, a refuzat să plece şi cu soția („Dacă n-o să mă lăsați să mă întorc, nevastă-mea, ostatecă, are să facă scandal - pentru reîntregirea familiei...")19. În iunie 1972 a plecat cu o viză turistică, pentru trei luni, în Austria, RFG, Franța, pe cheltuiala sa, fără ajutor de la Fondul Literar al Uniunii Scriitorilor.

Aflat la Frankfurt, a primit din țară câteva exemplare din As I Lay Dying, de Faulkner, pe care-l tradusese împreună cu Horia Florian Popescu, la editura Cartea Românească, cu titlul Pe patul de moarte, traducere semnată inițial cu pseudonim, la sugestia lui Gafița, de vreme ce nu avea drept de semnătură. Ajuns la Paris, i-a cunoscut pe Monica Lovinescu, Virgil Ierunca, Eugène Ionesco, Mircea Eliade, Emil Cioran ş.a. În octombrie 1972 a participat, în sfârşit, la Târgul de carte de la Frankfurt, unde a fost lansat romanul Uşa noastră cea de toate zilele (Die Tür). Interviurile date presei occidentale atunci şi articolele apărute în presa germană au avut darul de a agita şi mai mult puterea de la Bucureşti

\footnotetext{
16 „Romanul mai este şi un eseu despre «realitatea» românească; o fereastră deschisă înspre întorsăturile «sistemului» în care, chiar şi după «dezgheț» nimic substanțial nu s-a schimbat”. Giorgio Sandri, Un roman ,fugit” din România, în Il Tiempo, 20 nov. 1971, apud „Receptare critică”, în Paul Goma, Ostinato, Ed. Univers, Bucureşti, 1991.

17 Textul legii a fost publicat în Buletinul Oficial nr. 157/17 decembrie 1971, disponibil integral la http://www.cdep.ro/pls/legis/legis_pck.htp_act_text

?idt=1423 (accesată pe 6 iulie 2019).

18 Biobibliografie, loc. cit.

19 Ibid.
} 
şi brațul ei represiv, Securitatea. Unul dintre aceste articole, tradus în germană de Anneli Ute Gabanyi, a apărut în Die Zeit, Hamburg, 29 septembrie 1972, sub titlul Cenzură, autocenzură, para-literatură ${ }^{20}$, cu încadrările redacției: Problema principală a unui scrïtor român: Drumul scurt de la adevăr la minciună de Paul Goma.

La Paris, unde a ajuns şi soția sa în noiembrie, Goma a scris romanul Gherla, cu o continuare dedicată domiciliului obligatoriu la Lăteşti. Abia în seria de autor de la Curtea Veche, va apărea o ediție adevărată cu titlul Gherla-Lăteşti, în 2008, după o încercare neprofesionistă în 2007, la Anamarol.

Soții Goma au revenit acasă, în ciuda aşteptărilor autorităților comuniste, în iunie 1973. La vamă li s-au confiscat cărțile, între care „o carte de Willy Brandt, la care tocmai se ducea în vizită «Cancelarul» R.S.R.”21. Goma a amenințat Securitatea în scris că dacă nu-i sunt restituite cărțile în 24 de ore publică în Vest lista cărților interzise în România stăpânită de Ceauşescu. De teama scandalului internaţional care afecta nu doar imaginea regimului comunist, ci direct pe a lui Ceauşescu, i-au fost restituite toate cărțile, la 8 ore după transmiterea mesajului scris.

Cât lipsise, a fost dat afară din postul de redactor la România literară. Însă, a continuat să scrie şi să-i apară alte titluri în străinătate 1974: Elles étaient quatre (Uşa...), Gallimard; Ostinato în olandeză, editura Bruna \& Zoon, Utrecht; 1976: Gherla, Gallimard.

În ciuda nemulțumirilor exprimate în medii private de mulți scriitori, aceştia nu au avut niciodată curajul (unii spun „nebunia”) lui Paul Goma de a rupe cu regulile scrise şi nescrise ale conformismului, ale cenzurii şi autocenzurii. După cum arată o notă informativă din octombrie 1973, după ce s-a întors în țară, „Paul Goma cultivă pe lângă el o seamă de scriitori tineri cu care este adesea văzut la Casa Scriitorilor: Virgil Tănase, Cezar

\footnotetext{
20 „Vrei să spui (sau să scrii) ce ai de spus (sau de scris) şi ce ți se pare adevărat. Dar apoi vine un pumn care-ți închide gura şi te amuțeşte: taci, pentru că te supui cenzurii.

Ți-ar plăcea să spui (sau să scrii) ceea ce ai avea de spus (sau de scris) şi ceea ce ți se pare a fi adevărat. Şi vine un pumn care te amenință - îl ştii, te-a mai redus la tăcere şi-n trecut, te-a mai amenințat şi altădată: taci, pentru că te autocenzurezi.

Cândva, cu mult timp în urmă, ai vrut să spui (sau să scrii) ceva, dar un pumn îți închisese gura, te amenințase. Iar acum ai obosit. Ți se pare că ai vrea să spui ceva... - de fapt, nu mai ai nimic de spus... Ceva în legătură cu adevărul... dar cine mai cunoaşte adevărul...? (...) Aşa s-a născut în România, după întoarcerile-spre-îndărăt din 1968 şi din 1971, o para-literatură: cărți scrise-tipărite cu voie de la poliție; o literatură drăguță, simpatică, care nu spune nimic şi nu supără pe nimeni (decât «pe unii mici funcționari»), dar care atinge tiraje enorme: cenzura n-are nimic împotrivă ca un scriitor să publice, să aibă întâlniri cu cititorii, să fie filmat, intervievat, să fie declarat mare-scriitor, să fie (răs)plătit, câtă vreme nu spune adevărul.” textul poate fi citit integral în Goma, Scrìsuri (2010).

${ }^{21}$ Biobibliografie, loc. cit.
} 
Ivănescu, uneori şi Ileana Mălăncioiu, apoi Marius Robescu (accidental parcă). (...) [scriitorii] trăiesc într-o stare de spirit foarte proastă din cauza lipsurilor, a neputinței de a publica acele cărți la care țin, pe care le consideră «adevăratele lor 'opere'», a umilinței de a sta la cozi, la casiera Fondului Literar etc. Informatorul atrage atenția că dacă aceste situații nu vor fi rezolvate, «mi-e teamă că vom asista la lucruri neplăcute, iar dintre acestea nu cel din urmă ar fi încercarea de transport peste hotare a unor manuscrise»."22 $\mathrm{O}$ teamă, de altfel, neconfirmată istoric.

Pe 2 noiembrie 1975 s-a născut fiul soților Paul şi Ana Maria Goma - Filip-Ieronim.

Romanele Ostinato, Uşa..., Gherla au fost transmise, în foileton, la Radio Europa Liberă, ultimele două în lectura autorului, chiar dacă acesta se afla în România. În special lectura Gherlei a creat mare emoție printre ascultătorii români ai postului de radio, fiind ascultată şi de mulţi foşti deținuți politici, unii dintre ei colegi de detenție cu Goma, în închisoarea Gherla, în aceeaşi perioadă.

Se poate spune că scriitorul Paul Goma a lucrat permanent, fără să o facă în mod conştient cu un țel anume, altul decât libertatea interioară şi răzbaterea ei în spațiul public, la trezirea conştiințelor românilor, deveniți după 1965 tot mai conformi ideologic. Când în ianuarie 1977 a fost anunțată apariţia unei Charte 77 a cehilor şi slovacilor, „ogorul Goma” 23 , cum avea să-i spună un ziarist român exilat, era pregătit „să dea roade”. În ianuarie 1977, Goma nu pierde timpul, după ce eşuează în a adăuga şi alte semnături alături de a sa pe o Scrisoare deschisă adresată lui Pavel Kohout şi camarazilor săi. Era o scrisoare de solidarizare, adresată unuia dintre liderii din acel moment ai Chartei. Scrisoarea lui Goma a fost difuzată în prima decadă a lunii februarie de Radio Europa Liberă. Aproape concomitent, Goma i-a adresat o scrisoare deschisă lui Nicolae Ceauşescu însuşi. O scrisoare în care dictatorul este ridiculizat cu talent, încă de la formula de adresare („Domnului Nicolae Ceauşescu, Palatul Regal, Bucureşti”). Una dintre cele mai tari expresii este cea care denotă prăpastia abruptă dintre realitatea subjugată de control şi teroare, pe de o parte, şi minciuna oficială: „V-am mai spus: românii se tem de Securitate. Rezultă că, în România, doi inşi nu se tem de Securitate: Domnia Voastră şi cu mine"24.

În sfârşit, textul care desăvârşeşte ceea ce în mod îndreptăţit a fost numit Mişcarea Goma pentru drepturile omului este Scrisoarea deschisă adresată participanților la Conferința de la Belgrad, semnată inițial de opt

\footnotetext{
22 Apud, Diaconescu (2017, 83-87).

23 Av. Dumitrescu $(1977,3,5)$.

24 Paul Goma, Culoarea curcubeului (Cutremurul oamenilor 77), ed. îngrijită de Flori Bălănescu, Ed. Ratio et Revelatio, Oradea, 2015, p. 85.
} 
persoane, între care soții Goma. Scriitorul va strânge peste 400 de adeziuni, cele mai sonore nume de aderenți fiind al criticului literar Ion Negoițescu şi al psihiatrului Ion Vianu. Textul de solidarizare cel mai dramatic îi aparține, însă, medicului scriitor Ion Ladea, fost deținut politic (ca şi Ion Negoițescu, de altfel), a cărui scrisoare a fost difuzată de Europa Liberă în seara zilei de 13 aprilie 1977, în cadrul rubricii „Actualitatea Românească”:

PAUL GOMA,

Întârzierea scrisorii mele atestă pertinența ei, un gest ca al tău nu se poate evalua în măsura ce i se cuvenea în structura în care ne-a aruncat destinul. Te-am judecat cu măsura standard, cu măsura impusă de sistemul ce azi ne împresoară, te-am suspectat o zi provocator, care încerci să răscoleşti resursele latente ale unor oameni împietriți în tăcere. (...) Pe toți ne-a deformat sistemul, tuturor ne-a semănat în ogradă bănuiala şi teama, roadele terorii. Şi de teroare am avut cu toții parte 25 .

Textul scrisorii este mult mai amplu. După câteva decenii, Ladea avea să-şi sublinieze adeziunea la Mişcarea lui Goma din 1977, într-un interviu acordat Luciei Hossu-Longin în cadrul Memorialului durerii, după 1990. În termeni precişi, hotărâți, revoltați pe alocuri, fără să lase loc de interpretări, întrebat ce voia Goma, ce voiau cei care îl căutau pentru a semna Scrisoarea adresată Conferinței de la Belgrad (pentru Securitate şi Cooperare în Europa), Ladea răspunde:

Este ca şi cum eu sunt un cerşetor, că cerşetori erau, cerşeau de la Uniunea Sovietică, de la Ceauşescu dreptul de a respira, cerşetori care stau cu mâna întinsă şi trece cineva prin spate, le lasă o avere, ei se-ntorc puțin, scuipă după cel care pleacă şi nu ştiu cine a fost şi le-a lăsat averea! Sigur că dumneavoastră realizați, dar trebuie să fie trecută treaba asta în Cartea Recordurilor, atâta nesimțire încât să nu realizezi în ce mocirlă ai fost, în ce mocirlă morală ai fost. Se văd rezultatele care merg până în consecința lor materială, economică, până la capăt. Niciunde-n lume, comunismul unde a fost n-a lăsat decât tabula rasa. Ruşii n-au ce mânca. Indiferent c-a fost comunism în Germania sau în China, comunismul numai rezultatul ăsta îl are. Pornind de la degradarea morală despre care vorbesc eu acuma şi pe care a încercat s-o salveze Goma... şi argumentată fiind treaba asta cu consecințele economice şi fizice. Cum să nu ştii? Nu ştie lumea de România? $\mathrm{Nu}$ ştiți fraților c-ați fost în cel mai groaznic..., în cea mai groaznică mizerie, că era să zic o vorbă rea? Nu se poate treaba asta! A zice că nu ştii cine a fost Goma, înseamnă că nu ştii «cine sunt eu». Goma a fost reprezentantul care într-un moment care părea imposibil, într-un moment care nu accepta reconstituirea demnității de om, el a reconstituit-o. Că vă place, că nu... asta e cu totul altă treabă ${ }^{26}$.

25 ACNSAS, Fond Informativ, dos. nr 2 217, vol. 9, ff. 326-327.

26 Filmul integral, Memorialul Durerii - Episodul 31 - Paul Goma, disponibil la https://www.dailymotion.com/video/xrqv93 (accesat la 26.01.2019). 
Paul Goma a fost arestat pe 1 aprilie şi eliberat pe 6 mai 1977, numai la presiunile mass-media occidentale, după ce aproape fusese omorât, prin administrarea aconitinei, o substanță care nu poate fi depistată la autopsie (cu care s-a încercat asasinarea lui şi în 1982, prin intermediul ofițerului Matei Pavel Haiducu (Matei Pavel Hirsch, 1948-1998), care, însă, a defectat la francezi, zădărnicind planul regimului Ceauşescu de ai elimina pe scriitorii Virgil Tănase şi Paul Goma. După numeroase hărțuiri, presiuni şi amenințări, cei trei membri ai familiei Goma (Filip avea doi ani) au acceptat invitația repetată a Pen-Clubului Internațional şi au primit paşapoarte cu vize pentru Franța. Ajunşi pe 20 noiembrie cu avionul la Paris, au cerut imediat azil politic, statut pe care l-au avut tot restul vieții, atât Ana Maria Goma (decedată pe 5 septembrie 2017), cât şi Paul Goma (decedat pe 25 martie 2020), şi pe care încă îl are fiul lor, FilipIeronim Goma.

Aşa cum îl amenințase generalul Nicolae Pleşiță cu o zi înainte de plecare, Goma a avut parte de mâna lungă a revoluției. Toată experiența Mişcării pentru drepturile omului a fost trecută în cartea-document, considerată de unii scriitori şi critici un adevărat roman, Culoarea curcubeului, scrisă în 1978, primul an de refugiu politic la Paris, şi publicată în 1979 de editura Seuil, în traducerea lui Alain Paruit, cu titlul Le tremblement des hommes - Peut-on vivre en Roumanie aujourd'hui? Autorul însuşi o consideră, probabil şi din cauza marii apropieri temporale de evenimentele pe care le devoaleză, carte de mărturii. De menționat un aspect important: titlul în franceză - Le tremblement des hommes/Cutremurul oamenilor - a fost preluat de editură din reportajul jurnalistului Bernard Guetta (apărut în Le Nouvel Observateur), publicat sub titlul: „România, în 1977, a cunoscut două cutremure: unul de pământ, în 4 martie, altul al oamenilor, prin Mişcarea Goma”. Cartea a fost lansată în prezența lui Eugène Ionesco şi a lui Fernando Arrabal. În loc să se refere la cartea sa mărturisind despre o mișcare fără precedent în România comunistă (dar şi fără contracandidat până în 1989), al cărei principal martor a fost, Paul Goma a preferat să atragă atenția opiniei publice occidentale asupra a ceea ce considera că este atunci urgent pentru evoluția lucrurilor în România: constituirea Sindicatului Liber al Oamenilor Muncii din România (SLOMR). Agenția France-Presse anunța în 5 martie 1979:

Scriitorul român Paul Goma, care prezenta presei noua sa carte (...) a renunțat să vorbească despre sine şi a anunțat constituirea în România a unui Sindicat Liber, SLOMR. Paul Goma - acompaniat de Eugène Ionesco şi de Arrabal - a precizat că „pentru întâia oară după ocuparea României, românii s-au grupat într-un sindicat liber, în scopul de a apăra, nu doar drepturile sindicale, ci şi toate drepturile omului, fără excepție (...) România este a treia țară comunistă având un astfel de sindicat - după 
Polonia şi URSS - nucleul fiind constituit din semnatari ai Mişcării pentru apărarea drepturilor omului din primăvara anului 1977"27.

Ajuns aşadar la Paris, Goma află că Monica Lovinescu fusese atacată pe 18 noiembrie de doi „terorişti”, în realitate doi mercenari străini plătiți de Securitate. Regimul Ceauşescu încerca să-i închidă gura celei care l-a susținut mai mult decât oricine pe Paul Goma, de la microfonul Radio Europa Liberă. În 1981 şi 1982, Paul Goma a fost ținta a două planuri de eliminare gândite de Securitate şi subcontractate teroriştilor internaționali, între care celebrul Carlos „Şacalul”. Ambele atentate au fost imortalizate literar de scriitor în romanul Soldatul câinelui, apărut în 1983 cu titlul Chassée-croisé, la editura pariziană Hachette, în traducerea lui Alain Paruit. Între timp, mai apăruseră, în 1979, Gardă inversă (Garde inverse), în traducerea lui Şerban Cristovici, la Gallimard, iar în 1980, în neerlandeză, Culoarea curcubeului, cu titlul Met het woord tegen de muur (Cu capul în/de zid), la Elsevier Manteau, din Anvers.

O recunoaştere a meritelor sale este invitarea la constituirea în februarie 1978 a CIEL - Le Comité des Intellectuels pour l'Europe des Libertés, condusă de o preşedinție colegială constituită din: Eugène Ionesco, Alain Ravennes, Jean-Marie Domenach, François Fejtö şi Philippe Sollers. Pe 10 decembrie acelaşi an, scriitorul a participat la reuniunea de la Paris a organizației Amnesty International. Se împlineau 30 de ani de la adoptarea Declarației Universale a Drepturilor Omului. Cu acest prilej, România a fost criticată pentru lichidarea Mişcării pentru drepturile omului din primăvara anului 1977 şi pentru „pacificarea” Văii Jiului, prin reprimarea grevei minerilor, din august acelaşi an. Dar poate cea mai relevantă recunoaştere a venit din partea Ungariei, care în 1996, când se comemorau 40 de ani de la Revoluția maghiară (Revolta de la Budapesta, 1956) l-a decorat pe scriitorul român prin intermediul ambasadorului maghiar dla Paris, ca recunoaştere a solidarizării sale cu revoluționarii maghiari. Sigur că în toamna anului 1956 foarte mulți studenți români, din mai multe centre universitare, au ajuns în puşcăria comunistă din acelaşi motiv, însă Goma a fost singurul care a mers mai departe, prin afirmarea neîncetată în mod public a nevoii de libertate, până la a scoate România din tăcere şi a o pune pe harta luptei pentru drepturilor omului.

Continuă să publice în Occident traduceri ale romanelor sale scrise în limba română. În 1981 apărea la Hachette Patimile după Pitești, în traducerea lui Alain Paruit, cu titlul Les Chiens de mort, roman tradus în primăvara lui 1983 şi în olandeză sub titlul Het vierkante ei (Oul cubic), la Elsevier Manteau, Anvers, traducere de Andrea Borbel; tot în 1983, la

${ }^{27}$ Biobibliografie, loc. cit. 
Târgul de carte de la Frankfurt este lansată traducerea Patimilor... (Die rote Messe) în germană, de către Lucian Grigorowitsch, la editura Thule din Köln. Sub direcţia lui Paul Goma, apar în 1985 Czesław Miłosz, Le pays d'Ulro (eseu), şi Bujor Nedelcovici, Le Second messager (Al doilea mesager, roman). Continuă să scrie şi să publice, în traducere. În 1986 apare la editura Albin Michel, în traducerea franceză a lui Alain Paruit, romanul Bonifacia, iar un an mai târziu, la aceeaşi editură, de acelaşi traducător, Din Calidor (Le Calidor), considerat de mai mulți critici capodopera lui Goma. La începutul anului 1989 apare Din calidor în versiunea originală, în îngrijirea lui Ion Solacolu, la editura Dialog din Dietzenbach. In fapt, o fotocopie după dactilogramă - „Versiune originală, în dactilografierea autorului..."28.

Romanele şi scrierile publicistice ale lui Paul Goma au început să apară în româneşte începând din 1990, mai întâi la editura Humanitas, cu o frecvență aparent recuperatoare în primii ani (în mod inexplicabil, la scurtă vreme după apariție, editura a retras tirajul volumului Culoarea curcubeului şi l-a trimis la topit), care a slăbit mult şi pentru mulți ani, până la seriile de autor de la Curtea Veche (2008-2014) şi Ratio et Revelatio (2014-prezent). Interese extraliterare au ținut opera lui Paul Goma departe de o analiză corectă, profesionistă, dimpotrivă, încă mai sunt scriitori, critici literari şi oameni de cultură care, din diverse motive, se erijează în curele de transmisie ale unei mentalități comunist-securiste recurente.

\section{Bibliografie}

„Arhive personale şi familiale”, vol. 1, Repertoriu arhivistic, disponibil la http://arhivelenationale.ro/site/wpcontent/uploads/2017/o8/Arh._personale_si_familiale_I.pdf (accesat la 1.07.2020)

„Justificare biografică”, în ACNSAS, Fond Informativ, dosar nr. 2 217, vol. 3, ff. 51-55.

ACNSAS (Arhivele Consiliului Național pentru Studierea Arhivelor Securității), Fond Informativ, dosar nr. 2 217, vol. 2, f. 31.

ACNSAS, Fond Informativ, dos. nr 2 217, vol. 9, ff. 326-327.

Bălănescu, Flori. (2015). „Biobibliografie”, în Goma, Paul. (2015). Culoarea curcubeului (Cutremurul oamenilor 77), Ediție definitivă îngrijită de Flori Bălănescu. Oradea: Ed. Ratio et Revelatio, pp. 19-49.

Bălănescu, Flori. (2019). „Paul Goma în Arhivele Securității. De la revoltă intelectuală la opoziție deschisă, 1971-1977", în Paul Goma: Cuvântul basarabeanului răzvrătit. Prefață, selecție şi coordonare de Aliona Grati. Chişinău: Editura Ştiința, pp. 28-38.

Diaconescu, Ioana. (2017). Poezia ca act de insurgență. Cezar Ivănescu în arhivele Securității. Iaşi: Editura Junimea.

${ }^{28}$ Ibid. 
Dumitrescu, Cornel. (1977). „Ogorul semănat de Goma dă roade”, în Cuvântul românesc, Canada, Anul 2, Nr. 18, octombrie 1977.

Filmul integral, Memorialul Durerii - Episodul 31 - Paul Goma, disponibil la https://www.dailymotion.com/video/xrqv93 (accesat la 26.01.2019).

Goma, Paul. (2008). Gherla-Lăteşti, ediție îngrijită de Flori Bălănescu. Bucureşti: Ed. Curtea Veche.

Goma, Paul. (2010). Scrìsuri, vol. 1, 1971-1989. Bucureşti: Ed. Curtea Veche.

Goma, Paul. (2016). Justa, Ediție îngrijită de Flori Bălănescu. Oradea: Ed. Ratio et Revelatio. 